\title{
Extreme $\mathrm{N}_{2} \mathrm{O}$ accumulation in the coastal oxygen minimum zone off Peru
}

\author{
A. Kock ${ }^{1}$, D. L. Arévalo-Martínez ${ }^{1}$, C. R. Löscher ${ }^{1, a}$, and H. W. Bange ${ }^{1}$ \\ ${ }^{1}$ GEOMAR Helmholtz Centre for Ocean Research Kiel, Düsternbrooker Weg 20, 24105 Kiel, Germany

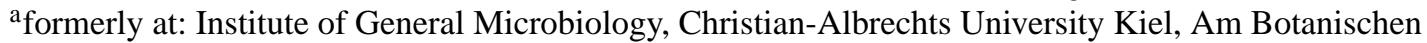 \\ Garten 1-9, 24118 Kiel, Germany \\ Correspondence to: A. Kock (akock@geomar.de)
}

Received: 31 May 2015 - Published in Biogeosciences Discuss.: 8 July 2015

Revised: 25 January 2016 - Accepted: 27 January 2016 - Published: 12 February 2016

\begin{abstract}
Depth profiles of nitrous oxide $\left(\mathrm{N}_{2} \mathrm{O}\right)$ were measured during six cruises to the upwelling area and oxygen minimum zone (OMZ) off Peru in 2009 and 2012/2013, covering both the coastal shelf region and the adjacent open ocean. $\mathrm{N}_{2} \mathrm{O}$ profiles displayed a strong sensitivity towards oxygen concentrations. Open ocean profiles with distances to the shelf break larger than the first baroclinic Rossby radius of deformation showed a transition from a broad maximum close to the Equator to a double-peak structure south of $5^{\circ} \mathrm{S}$ where the oxygen minimum was more pronounced. Maximum $\mathrm{N}_{2} \mathrm{O}$ concentrations in the open ocean were about $80 \mathrm{nM}$. A linear relationship between $\Delta \mathrm{N}_{2} \mathrm{O}$ and apparent oxygen utilization (AOU) could be found for measurements within the upper oxycline, with a slope similar to studies in other oceanic regions. In contrast, $\mathrm{N}_{2} \mathrm{O}$ profiles close to the shelf revealed a much higher variability, and $\mathrm{N}_{2} \mathrm{O}$ concentrations higher than $100 \mathrm{nM}$ were often observed. The highest $\mathrm{N}_{2} \mathrm{O}$ concentration measured at the shelf was $\sim 850 \mathrm{nM}$. Due to the extremely sharp oxygen gradients at the shelf, $\mathrm{N}_{2} \mathrm{O}$ maxima occurred in very shallow water depths of less than $50 \mathrm{~m}$. In the coastal area, a linear relationship between $\Delta \mathrm{N}_{2} \mathrm{O}$ and AOU could not be observed as extremely high $\Delta \mathrm{N}_{2} \mathrm{O}$ values were scattered over the full range of oxygen concentrations. The data points that showed the strongest deviation from a linear $\Delta \mathrm{N}_{2} \mathrm{O} / \mathrm{AOU}$ relationship also showed signals of intense nitrogen loss. These results indicate that the coastal upwelling at the Peruvian coast and the subsequent strong remineralization in the water column causes conditions that lead to extreme $\mathrm{N}_{2} \mathrm{O}$ accumulation, most likely due to the interplay of intense mixing and high rates of remineralization which lead to a rapid switching of the OMZ waters between
\end{abstract}

anoxic and oxic conditions. This, in turn, could trigger incomplete denitrification or pulses of increased nitrification with extreme $\mathrm{N}_{2} \mathrm{O}$ production.

\section{Introduction}

Nitrous oxide $\left(\mathrm{N}_{2} \mathrm{O}\right)$ acts as a strong atmospheric greenhouse gas and contributes substantially to the stratospheric ozone depletion (IPCC, 2013; WMO, 2011). The ocean is a major source for $\mathrm{N}_{2} \mathrm{O}$ as it is naturally produced in the water column (Ciais et al., 2013; Bange, 2008). While in large parts of the surface ocean $\mathrm{N}_{2} \mathrm{O}$ concentrations are close to saturation, high emissions of $\mathrm{N}_{2} \mathrm{O}$ have been observed in upwelling areas where subsurface waters enriched in $\mathrm{N}_{2} \mathrm{O}$ are transported to the surface (e.g. Nevison et al., 2004). The global distribution of $\mathrm{N}_{2} \mathrm{O}$ in the ocean is closely linked to the oceanic oxygen distribution, and particularly high supersaturations are found in upwelling areas which overlay pronounced oxygen minimum zones (OMZ), e.g. in the Arabian Sea (Bange et al., 2001) or in the eastern South Pacific Ocean (Charpentier et al., 2010).

These OMZs are key regions for marine nitrogen $(\mathrm{N})$ cycling where active $\mathrm{N}$ loss via canonical denitrification and anaerobic ammonium oxidation (anammox) takes place. Particularly in areas where the OMZ is fuelled by high export production, high rates of denitrification and anammox, but also other $\mathrm{N}$ transformation processes, such as nitrification, have been observed (Hu et al., 2015; Kalvelage et al., 2013). Oceanic $\mathrm{N}_{2} \mathrm{O}$ is mainly produced by nitrification and deni- 
trification, and the interplay of these processes governs the $\mathrm{N}_{2} \mathrm{O}$ distribution in OMZs (Bange, 2008).

The relationship between $\mathrm{N}_{2} \mathrm{O}$ and oxygen concentrations in the ocean in often described by comparing excess $\mathrm{N}_{2} \mathrm{O}$ $\left(\Delta \mathrm{N}_{2} \mathrm{O}\right)$ and the apparent oxygen utilization (AOU). As nitrification is one major process accompanying the remineralization of organic matter, a positive correlation between $\Delta \mathrm{N}_{2} \mathrm{O}$ and $\mathrm{AOU}$ is often interpreted as an indication for nitrification as the main $\mathrm{N}_{2} \mathrm{O}$ production pathway (e.g. Walter et al., 2006; Forster et al., 2009). Nitrification can either be performed by bacteria (Arp and Stein, 2003) or archaea (Walker et al., 2010). Recent studies indicate that archaea may dominate marine $\mathrm{N}_{2} \mathrm{O}$ production under oxic conditions (Löscher et al., 2012; Santoro et al., 2011). The production mechanisms and environmental controls of archaeal $\mathrm{N}_{2} \mathrm{O}$ production are subject to ongoing research, however (Stieglmeier et al., 2014).

An increase in the $\Delta \mathrm{N}_{2} \mathrm{O} / \mathrm{AOU}$ ratio at low oxygen concentrations has been observed in several studies in different oceanic areas with reduced oxygen concentrations (Ryabenko et al., 2012; Upstill-Goddard et al., 1999; De Wilde and Helder, 1997). This could be explained by several processes: during nitrification, $\mathrm{N}_{2} \mathrm{O}$ can either be produced as a side product from the oxidation of ammonium to nitrite, or from the reduction of nitrite to $\mathrm{N}_{2} \mathrm{O}$, a process known as nitrifier-denitrification (Stein, 2011). Nitrifier-denitrification has been identified as an important production pathway of $\mathrm{N}_{2} \mathrm{O}$ at low oxygen concentrations and may thus be responsible for the increased $\mathrm{N}_{2} \mathrm{O}$ production under these conditions (Ni et al., 2014). An increase in the $\mathrm{N}_{2} \mathrm{O}$ yield of nitrification has indeed been observed in laboratory experiments with bacterial (Goreau et al., 1980) and archaeal ammonium oxidizers (Löscher et al., 2012). The extent to which ammonium oxidation or the nitrifier-denitrification pathway are responsible for $\mathrm{N}_{2} \mathrm{O}$ production is yet not well determined (Ostrom et al., 2000; Ni et al., 2014), particularly for archaeal nitrification (Löscher et al., 2012; Santoro et al., 2011; Stieglmeier et al., 2014).

Additional $\mathrm{N}_{2} \mathrm{O}$ production from denitrification has also been proposed as a potential mechanism leading to an increased $\Delta \mathrm{N}_{2} \mathrm{O} / \mathrm{AOU}$ at low oxygen concentrations (e.g. Farías et al., 2009; Ji et al., 2015). During denitrification, the canonical reduction of nitrate to molecular nitrogen, $\mathrm{N}_{2} \mathrm{O}$ evolves as an intermediate product. Denitrification is stimulated by the supply of organic carbon or hydrogen sulfide (Chang et al., 2014; Dalsgaard et al., 2014; Galan et al., 2014), and active denitrification is restricted to suboxic to anoxic conditions (e.g. Firestone et al., 1980; Dalsgaard et al., 2014). Depending on the environmental conditions, $\mathrm{N}_{2} \mathrm{O}$ production or consumption due to denitrification can be observed in the environment. There has been evidence that $\mathrm{N}_{2} \mathrm{O}$ consumption is more sensitive to trace amounts of oxygen than $\mathrm{N}_{2} \mathrm{O}$ production. This could lead to $\mathrm{N}_{2} \mathrm{O}$ accumulation when oxygen is present at low concentrations (Tiedje, 1988). Exceptionally high $\mathrm{N}_{2} \mathrm{O}$ concentrations off the West Indian
Coast were thus associated with an increased $\mathrm{N}_{2} \mathrm{O}$ production from denitrification during transient oxygen concentrations (Naqvi et al., 2000). In a recent study it was furthermore shown that $\mathrm{N}_{2} \mathrm{O}$ production from denitrification could be stimulated by $\mathrm{H}_{2} \mathrm{~S}$ addition (Dalsgaard et al., 2014) which could indicate a coupling between $\mathrm{N}_{2} \mathrm{O}$ production and sulfur cycling.

At oxygen concentrations below a threshold value of 4$10 \mu \mathrm{M}$, (Nevison et al., 2003; Ryabenko et al., 2012; Cornejo and Farias, 2012), consumption of $\mathrm{N}_{2} \mathrm{O}$ in the water column is observed, which leads to a breakdown in the previously described positive $\Delta \mathrm{N}_{2} \mathrm{O} / \mathrm{AOU}$ relationship. The exact oxygen concentration at which net $\mathrm{N}_{2} \mathrm{O}$ consumption starts is not yet well determined, however (Cornejo and Farias, 2012; Zamora et al., 2012). $\mathrm{N}_{2} \mathrm{O}$ consumption has been associated with denitrification as the only known process to remove $\mathrm{N}_{2} \mathrm{O}$ in OMZ waters (Cornejo and Farias, 2012). Although rate measurements only rarely detected active denitrification in the water column of the ETSP (Kalvelage et al., 2013; Hamersley et al., 2007; Thamdrup et al., 2006), the widespread $\mathrm{N}_{2} \mathrm{O}$ consumption in the OMZ core is an indicator for active denitrification (Farias et al., 2007).

There is a strong indication that at low oxygen concentrations nitrification and denitrification may take place in close proximity (Kalvelage et al., 2011), and the $\mathrm{N}_{2} \mathrm{O}$ production and consumption under these conditions are strongly influenced by the interaction of both processes (Ji et al., 2015). Measurements of $\mathrm{N}_{2} \mathrm{O}$ consumption rates in the eastern tropical North Pacific Ocean (ETNP) furthermore provided evidence for a rapid $\mathrm{N}_{2} \mathrm{O}$ cycling, although depth profiles of $\mathrm{N}_{2} \mathrm{O}$ seemed to be relatively invariant over time (Babbin et al., 2015). These quasi-stable conditions may be disturbed by rapid changes in the environmental conditions.

The eastern tropical South Pacific Ocean (ETSP) harbours one of the four major eastern boundary upwelling systems (EBUS): alongshore trade winds induce offshore Ekman transport of the surface water masses which leads to strong coastal upwelling off Peru and Chile (Chavez and Messié, 2009). While year-round upwelling and high primary productivity can be observed along the Peruvian coast (Messie et al., 2009), the highest upwelling intensity can be observed during austral winter, whereas primary production seems to be higher during autumn and spring (Pennington et al., 2006), which may be caused by nutrient and light limitation during phases of intense upwelling (Echevin et al., 2008).

The region is influenced by strong seasonal and interannual variability caused by the influence of Equatorial Kelvin waves and the El Niño Southern Oscillation (ENSO). ENSO could cause the interruption of the upwelling during El Niño events (Dewitte et al., 2012; Graco et al., 2016). While the OMZ core is largely unaffected by ENSO, a deepening of the upper oxycline and the re-oxygenation of the Peruvian shelf due to the propagation of coastal trapped waves can be observed (Gutierrez et al., 2008). 

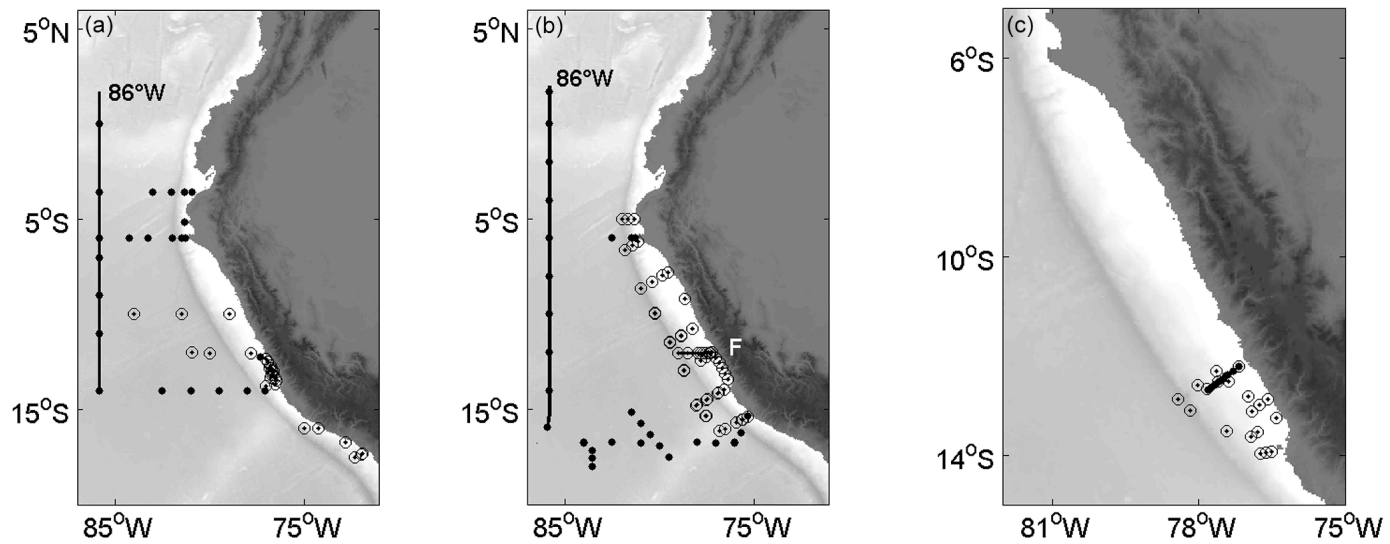

Figure 1. Station maps of the sampled $\mathrm{N}_{2} \mathrm{O}$ stations from cruises (a) M77-3, December 2008-January 2009 (•) and M77-4, January-February $2009(\odot)$, (b) M90, November $2012(\bullet)$ and M91, December $2012(\odot)$, (c) M92, January $2013(\bullet)$ and M93, February-March $2013(\odot)$. Section annotations in (a) and (b) correspond to the vertical sections shown in Figs. 2 and 3.

The ETSP is characterized by one of the largest and most intense OMZs in the oceans, extending from the Peruvian shelf about $1000 \mathrm{~km}$ offshore with a maximum thickness of more than $600 \mathrm{~m}$ (Fuenzalida et al., 2009). It is located in the shadow zone of large ocean current systems which leads to a sluggish ventilation and long residence times of waters within the OMZ (Karstensen et al., 2008). Equatorial current bands such as the Equatorial Undercurrent (EUC) and the Southern Subsurface Countercurrents (SSCC) supply waters to the ETSP which leads to slightly elevated oxygen concentrations in the northern part of our study area, with minimum oxygen concentrations of 10-20 $\mu \mathrm{M}$ (Stramma et al., 2010), whereas oxygen concentrations below $3 \mu \mathrm{M}$ are common in the OMZ core south of $5^{\circ} \mathrm{S}$ (Paulmier et al., 2006). The Equatorial current bands also feed the poleward Peru-Chile Undercurrent (PCUC) which is the main source for waters upwelled along the coast (Montes et al., 2010; Chaigneau et al., 2013) and which transports Equatorial Subsurface Water (ESSW) southward. During its spreading, the ESSW is subject to oxygen depletion and mixing with surrounding water masses, e.g. the Antarctic Intermediate Water (AAIW) below and the Eastern South Pacific Intermediate Water (ESPIW) which originates from the South (Wyrtki, 1967; Chaigneau et al., 2013). Mixing of different water masses in the upwelling zone creates a distinct coastal water mass which is called Cold Coastal Water (CCW; Pietri et al., 2013).

High primary production and high remineralization rates in the underlying waters lead to a further drawdown in subsurface oxygen concentrations to near-depleted conditions (Karstensen et al., 2008). Active $\mathrm{N}$ loss is observed in large parts of the OMZ which is reflected in a pronounced secondary nitrite maximum and a strong nitrogen deficit in the OMZ core (Codispoti et al., 1986). The OMZ furthermore frequently extends over large parts of the Peruvian shelf where sulfidic conditions within the water column can be observed (Schunck et al., 2013).
Here we present $\mathrm{N}_{2} \mathrm{O}$ measurements in the water column off Peru from six measurement campaigns in the ETSP. Previous depth profile measurements in this area showed a pronounced double-peak structure off South Peru which merged into a broad maximum north of $5^{\circ} \mathrm{N}$ (Cornejo and Farias, 2012; Ryabenko et al., 2012). Surface $\mathrm{N}_{2} \mathrm{O}$ measurements off Peru furthermore revealed extraordinarily high emissions from the Peruvian shelf area which corresponded to extremely high surface and subsurface $\mathrm{N}_{2} \mathrm{O}$ concentrations (Arévalo-Martínez et al., 2015).

\section{Methods}

In total, 146 depth profiles $(0-4200 \mathrm{~m})$ of $\mathrm{N}_{2} \mathrm{O}$ were measured on two cruises between December 2008 and February 2009 (M77-3 \& M77-4) and four cruises between October 2012 and March 2013 (M90-M93) to the upwelling area and the adjacent open ocean off Peru onboard the German research vessel Meteor. The Southern Oscillation Indices (http://www.ncdc.noaa.gov/teleconnections/ enso/indicators/soi/) from 2008/2009 and 2012/2013 did not indicate the presence of an El Niño event during our measurement campaigns and similar conditions between both measurement campaigns could be expected. The locations of the sampled stations are shown in Fig. 1. While the M774 and M90 cruises mainly covered the open-ocean area, the M77-3 and M91-M93 cruises mainly took place in the Peruvian shelf area. The work was part of the German DFG collaborative research project (SFB) 754 (https://www.sfb754. de/) and the BMBF project SOPRAN (Surface Ocean PRocesses in the ANthropocene, http://sopran.pangaea.de/). The $\mathrm{N}_{2} \mathrm{O}$ data set described here has been archived in MEMENTO, the MarinE MethanE and NiTrous Oxide database (https://memento.geomar.de; Kock and Bange, 2015). 
Triplicate samples were taken from $10 \mathrm{~L}$ Niskin bottles mounted on a rosette water sampler or a pump-CTD (M77-3) in $25 \pm 0.11 \mathrm{~mL}$ (M77-3 \& M77-4) and $20 \pm 0.14 \mathrm{~mL}$ (M90M93) opaque glass vials and sealed with butyl rubber stoppers and aluminium caps, thereby avoiding the inclusion of air bubbles.

Samples were treated with $0.2 \mathrm{~mL}$ (M77-3 \& M77-4) and $0.05 \mathrm{~mL}$ (M90-M93) of a saturated mercuric chloride solution directly after the sampling to inhibit microbial $\mathrm{N}_{2} \mathrm{O}$ production or consumption. The samples were either analysed onboard (M77-3 \& M77-4, M91, partly M90 \& M93) within a few days or shipped to GEOMAR by air freight for later analysis (M92, partly M90 \& M93). Samples that were shipped to Germany were additionally sealed with paraffin wax and stored upside down to avoid the formation of air bubbles in the samples due to temperature and pressure changes during transportation.

Samples were analysed using a static equilibration method: $10 \mathrm{~mL}$ helium $(99.9999 \%$, AirLiquide, Düsseldorf, Germany) was manually injected into each vial which was equipped with a second syringe to collect the overflowing water. Vials with added headspace were vigorously shaken for about $20 \mathrm{~s}$ and allowed to equilibrate at ambient temperature for a minimum of 2 hours. A subsample of the equilibrated headspace was manually injected into a GC-ECD system (Hewlett-Packard 5890 Series II, Agilent Technologies, Santa Clara, CA, USA), equipped with a $6^{\prime} 1 / 8^{\prime \prime}$ packed column (molsieve, $5 \AA$, W. R. Grace \& Co.-Conn., Columbia, MY). The GC was operated at $190^{\circ} \mathrm{C}$, using argon/methane (95\%/5\%, ECD purity, AirLiquide, Düsseldorf, Germany) as carrier gas at a flow rate of $30 \mathrm{~mL} \mathrm{~min}^{-1}$.

The GC was calibrated on a daily basis with a minimum of 2 (M77-3 \& M77-4) or 4 (M90-M93) different standard gas mixtures $\left(\mathrm{N}_{2} \mathrm{O}\right.$ in synthetic air, Deuste-Steininger $\mathrm{GmbH}$, Mühlhausen, Germany and Westfalen AG, Münster, Germany). Standard gases were either injected as pure gas or further diluted with helium $(1: 3,1: 1$ or $3: 1)$ to obtain additional standard gas concentrations. Our standard gases were calibrated against NOAA primary standards at the Max Planck Institute for Biogeochemistry in Jena, Germany, if the standard gas concentrations were within the calibration range of the NOAA gases. Gases with $\mathrm{N}_{2} \mathrm{O}$ concentrations outside the NOAA calibration range were internally calibrated using an LGR $\mathrm{N}_{2} \mathrm{O} / \mathrm{CO}$ analyser (Los Gatos Research, Mountain View, CA, USA), which was proven to have a linear response and minimal drift within the calibration range (Arévalo-Martínez et al., 2013). The $\mathrm{N}_{2} \mathrm{O}$ concentration in the samples was calculated according to Walter et al. (2006) using the solubility function of Weiss and Price (1980). The average precision of the measurements, calculated as median standard deviation from triplicate measurements, was $0.7 \mathrm{nM}$.

$\Delta \mathrm{N}_{2} \mathrm{O}$ was calculated as the difference between the in situ concentration $\left[\mathrm{N}_{2} \mathrm{O}\right]_{w}$ and the equilibrium concentration
$\left[\mathrm{N}_{2} \mathrm{O}\right]_{\mathrm{eq}}:$

$\Delta \mathrm{N}_{2} \mathrm{O}=\left[\mathrm{N}_{2} \mathrm{O}\right]_{w}-\left[\mathrm{N}_{2} \mathrm{O}\right]_{\mathrm{eq}}$.

We used the contemporary atmospheric mixing ratio measured at Cape Grim, Tasmania (http://agage.mit.edu/data/ agage-data) for the calculation of $\left[\mathrm{N}_{2} \mathrm{O}\right]_{\text {eq }}$. This calculation underestimates the $\mathrm{N}_{2} \mathrm{O}$ excess in subsurface waters which have been isolated from the surface for a long time as it does not account for the increase in the atmospheric mixing ratio since the beginning of the industrial revolution (Freing et al., 2009). The use of the contemporary $\mathrm{N}_{2} \mathrm{O}$ mixing ratio of 2013 would lead to a maximum $\sim 17 \%$ overestimate of $\left[\mathrm{N}_{2} \mathrm{O}\right]_{\text {eq }}$, thus leading to only a small error compared to the maximum $\mathrm{N}_{2} \mathrm{O}$ concentrations measured in our study, and the use of the contemporary atmospheric mixing ratio still allows a qualitative analysis of the $\Delta \mathrm{N}_{2} \mathrm{O} /$ AOU relationship in order to investigate the formation and consumption processes of $\mathrm{N}_{2} \mathrm{O}$.

The potential temperature of the water parcel at a certain depth was calculated using the Gibbs Seawater Oceanographic Toolbox (McDougall and Barker, 2011).

Oxygen concentrations were measured either with a Seabird (M77-3 \& M77-4: SBE-5; M90-M93: SBE 43) oxygen sensor (Sea-Bird Electronics, Bellevue, WA, USA) mounted on the CTD rosette or from $100 \mathrm{~mL}$ discrete samples taken from the Niskin bottles and analysed using the Winkler titration method (Grasshoff et al., 1999). The oxygen sensor was calibrated against the Winkler measurements.

Recent studies using highly sensitive STOX (Switchable Trace amount Oxygen) sensors for oxygen measurements indicate that measurements with conventional oxygen sensors that are calibrated against Winkler measurements may be biased towards higher concentrations at near-zero oxygen conditions. Thamdrup et al. (2012) therefore argued that anoxic conditions are prevalent in the core of the Peruvian OMZ where oxygen concentrations of several $\mu \mathrm{M}$ have been found using the conventional Winkler-calibrated measurements. As STOX sensor measurements were not available for all measurement campaigns presented here, the minimum oxygen measurements reported here from the core of the OMZ (3$5 \mu \mathrm{M}$ ) should be considered as an overestimation.

The Apparent Oxygen Utilization (AOU) was calculated from the oxygen concentrations $\left[\mathrm{O}_{2}\right]_{w}$ using the CSIRO SeaWater library, version 3.2 (http://www.cmar.csiro.au/ datacentre/ext_docs/seawater.htm) to calculate oxygen saturation $\left[\mathrm{O}_{2}\right]_{\mathrm{eq}}$ :

$\mathrm{AOU}=\left[\mathrm{O}_{2}\right]_{\mathrm{eq}}-\left[\mathrm{O}_{2}\right]_{w}$.

Nutrient samples $\left(\left[\mathrm{NO}_{3}^{-}\right],\left[\mathrm{NO}_{2}^{-}\right],\left[\mathrm{PO}_{4}^{3-}\right],\left[\mathrm{NH}_{4}^{+}\right]\right)$from the CTD rosette were analysed onboard following the nutrient analysis methods according to Hansen et al. (1999). Samples taken from the pump-CTD during M77-3 were stored at $-20^{\circ} \mathrm{C}$ and shipped to Germany for later analysis. $\mathrm{N}^{\prime}$ was 

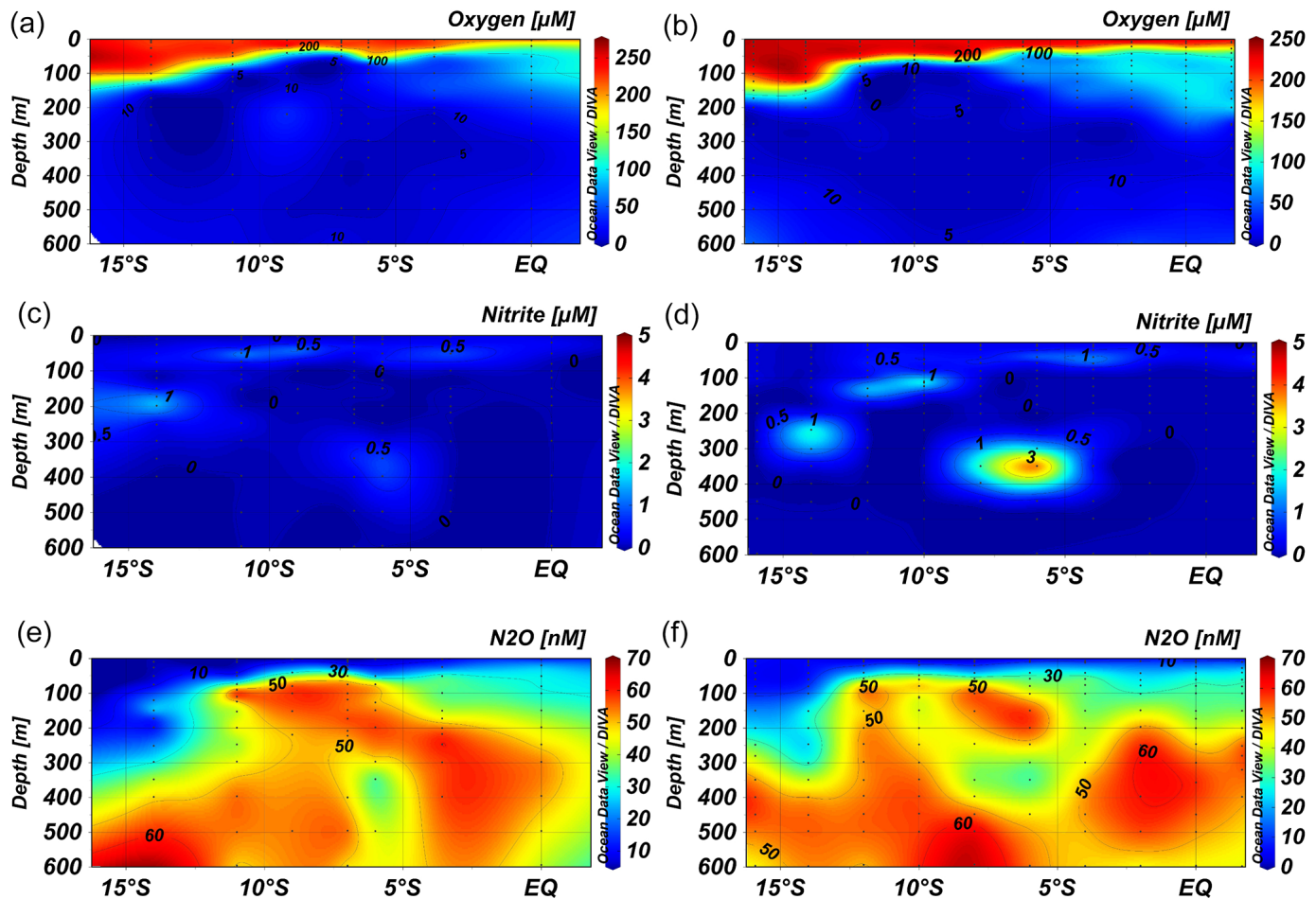

Figure 2. Spatial distributions of oxygen (a, b), nitrite (c, d) and $\mathrm{N}_{2} \mathrm{O}(\mathbf{e}, \mathbf{f})$ along $86^{\circ} \mathrm{W}$ during M77-4 (2009, a, c, e) and M90 (2012, b, d, f). Small dots indicate location and depth of the discrete samples. Data gridding: ODV/DIVA.

calculated as a measure for the nitrogen deficit from the nitrate $\left(\left[\mathrm{NO}_{3}^{-}\right]\right)$, nitrite $\left(\left[\mathrm{NO}_{2}^{-}\right]\right)$and phosphate $\left(\left[\mathrm{PO}_{4}^{3-}\right]\right)$ concentrations as follows (Altabet et al., 2012):

$\mathrm{N}^{\prime}=\left(\left[\mathrm{NO}_{3}^{-}\right]+\left[\mathrm{NO}_{2}^{-}\right]\right)-16\left[\mathrm{PO}_{4}^{3-}\right]$

To distinguish between coastal and open-ocean stations we calculated the distance of each station from the continental slope ( $2000 \mathrm{~m}$ isobath) and used the first baroclinic Rossby radius of deformation as described by Chelton et al. (1998) as threshold distance for stations that were influenced by coastal upwelling.

\section{Results}

\subsection{Spatial distribution of oxygen, nutrients and $\mathrm{N}_{2} \mathrm{O}$}

The distribution of oxygen, nitrite and $\mathrm{N}_{2} \mathrm{O}$ along an offshore section between $16^{\circ} \mathrm{S}$ and $2^{\circ} \mathrm{N}$ at $86^{\circ} \mathrm{W}$ from the M77-4 cruise in 2009 and the M90 cruise in 2012 is shown in Fig. 2; a coastal cross-shelf section along $12^{\circ} \mathrm{S}$ with the distribution of oxygen, nutrients, $\mathrm{N}^{\prime}$ and $\mathrm{N}_{2} \mathrm{O}$ is shown in Fig. 3 and selected depth profiles of oxygen, $\mathrm{N}_{2} \mathrm{O}$ and potential density $\left(\sigma_{\theta}\right)$ as well as nitrate, nitrite, ammonium and $\mathrm{N}^{\prime}$ are shown in Fig. 4.

Along $86^{\circ} \mathrm{W}$, a similar distribution of oxygen, nitrite and $\mathrm{N}_{2} \mathrm{O}$ was observed during M77-4 and M90. Oxygen and $\mathrm{N}_{2} \mathrm{O}$ profiles concentrations were close to saturation in the mixed layer. The mixed layer depth increased from below $20 \mathrm{~m}$ in the northern part of the section to more than $100 \mathrm{~m}$ south of $15^{\circ} \mathrm{S}$. Below the mixed layer, a sharp oxycline with a decrease to oxygen concentrations below $10 \mu \mathrm{M}$ was observed south of $5^{\circ} \mathrm{S}$, whereas in the northern part of the section, below the mixed layer oxygen concentrations only decreased to $\sim 100 \mu \mathrm{M}$ in the upper $200 \mathrm{~m}$ and further dropped to concentrations $\sim 10 \mu \mathrm{M}$ between 200 and $500 \mathrm{~m}$. Minimum oxygen concentrations in the water column increased towards the north from below $5 \mu \mathrm{M}$ south of $5^{\circ} \mathrm{S}$ to $\sim 10 \mu \mathrm{M}$ at the Equator.

The nitrite distribution revealed a primary maximum at the base of the mixed layer with maximum nitrite concentrations below $1.5 \mu \mathrm{M}$. This primary maximum is frequently observed in the ocean and is usually associated with nitrification (Codispoti and Christensen, 1985). South of $5^{\circ} \mathrm{S}$, a secondary nitrite maximum was observed within the OMZ where oxygen concentrations fell below $5 \mu \mathrm{M}$. Nitrite concentrations in the secondary maximum reached up to $\sim 4 \mu \mathrm{M}$.

Along the cross-shelf section at $12^{\circ} \mathrm{S}$, the upper $\mathrm{OMZ}$ boundary significantly became shallower towards the coast as a signal of upwelling, with a well-oxygenated mixed layer of $\sim 50 \mathrm{~m}$ in the open ocean and a mixed layer depth of less than $5 \mathrm{~m}$ on the shelf. Oxygen was strongly undersaturated in the surface waters on the shelf as a result of upwelling of waters from the underlying OMZ (Fig. 4). Elevated phosphate concentrations in the surface waters at the coast also reflected 

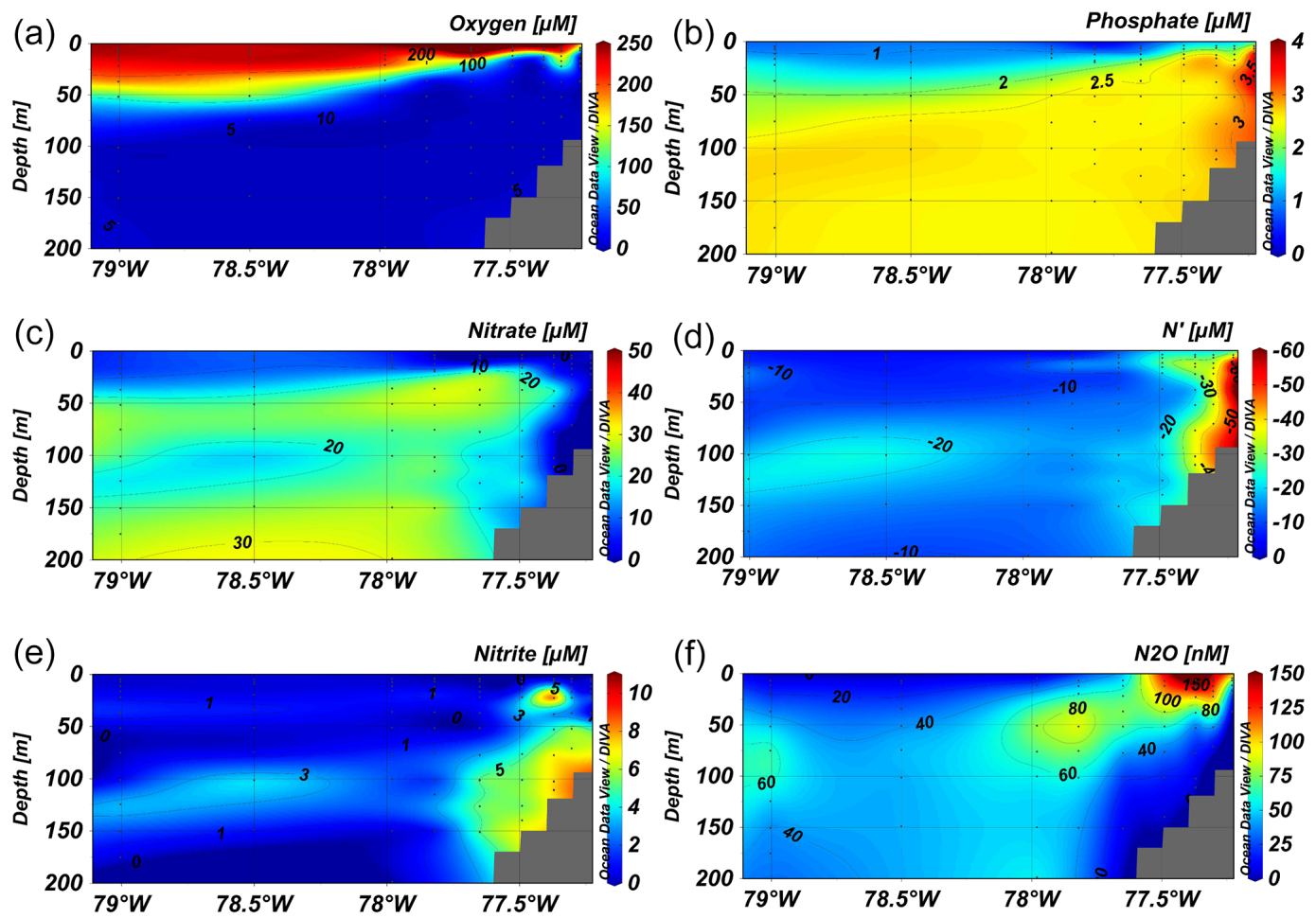

Figure 3. Cross-shelf distribution of (a) oxygen, (b) phosphate, (c) nitrate, (d) $\mathrm{N}^{\prime}$, (e) nitrite and (f) $\mathrm{N}_{2} \mathrm{O}$ during M91 (section F).

the upwelling on the shelf, whereas nitrate was depleted in the water column and the surface waters close to the coast, which was also reflected in very low $\mathrm{N}^{\prime}$ values at the inshore stations (Fig. 3). A primary and secondary nitrite maximum at the base of the mixed layer and in the OMZ core was observed throughout the cross-shelf section, but both maxima were much more pronounced on the shelf than in the deep waters (Fig. 3).

The $\mathrm{N}_{2} \mathrm{O}$ distribution along $86^{\circ} \mathrm{W}$ could be divided into two different regimes: north of $5^{\circ} \mathrm{S}$, a broad $\mathrm{N}_{2} \mathrm{O}$ maximum with concentrations of $\sim 60 \mathrm{nM}$ coincided with the depth of the oxygen minimum, whereas in the southern part of the section, the $\mathrm{N}_{2} \mathrm{O}$ profiles revealed a double-peak structure with a sharp $\mathrm{N}_{2} \mathrm{O}$ maximum in the upper and lower oxycline and $\mathrm{N}_{2} \mathrm{O}$ depletion in the OMZ core, also coinciding with the secondary nitrite maximum. This shape of $\mathrm{N}_{2} \mathrm{O}$ profiles has been observed in OMZ regions before (e.g. Law and Owens, 1990; Cohen and Gordon, 1978). The transition from profiles with a broad $\mathrm{N}_{2} \mathrm{O}$ peak to a double-peak structure coincided with the decrease in the minimum oxygen concentrations towards the south. $\mathrm{N}_{2} \mathrm{O}$ depletion was observed in profiles were oxygen concentrations dropped below $\sim 5 \mu \mathrm{M}$ and nitrite accumulation was observed.

Compared to the offshore waters, the $\mathrm{N}_{2} \mathrm{O}$ distribution on the shelf and in the adjacent waters showed a much larger variability. $\mathrm{N}_{2} \mathrm{O}$ depletion was in fact observed at oxygen concentrations below $5 \mu \mathrm{M}$, too. While several $\mathrm{N}_{2} \mathrm{O}$ profiles revealed a shape similar to the offshore profiles, an overall characteristic shape could not be identified; profiles with a subsurface $\mathrm{N}_{2} \mathrm{O}$ maximum in the oxycline were observed as well as profiles with multiple maxima or a surface $\mathrm{N}_{2} \mathrm{O}$ maximum (Fig. 4). While $\mathrm{N}_{2} \mathrm{O}$ concentrations in the offshore waters did not exceed $80 \mathrm{nM}, \mathrm{N}_{2} \mathrm{O}$ concentrations above $100 \mathrm{nM}$ were frequently observed at the shelf. Several profiles showed an extreme $\mathrm{N}_{2} \mathrm{O}$ accumulation with concentrations above $500 \mu \mathrm{M}$ (maximum $\sim 850 \mathrm{nM}$; Fig. 4). The location and shape of the $\mathrm{N}_{2} \mathrm{O}$ maxima in the different profiles was highly variable, which resulted in a very patchy distribution of $\mathrm{N}_{2} \mathrm{O}$ in the water column (Fig. 3).

\section{2 $\quad \mathrm{N}_{2} \mathrm{O}$ in different water masses of the ETSP}

The water mass distribution in our data set agrees well with the data presented by Pietri et al. (2014; Fig. 5). Due to the larger area covered by our measurements our data showed a broader scattering, but we could identify the same water masses in our data: below $500 \mathrm{~m}$, both the coastal and the offshore profiles carry relatively fresh $(S \sim 34.8)$ and cool $\left(T_{\text {pot }} \sim 5^{\circ} \mathrm{C}\right.$ ) Antarctic Intermediate Water (AAIW; Pietri et al., 2014) that carried relatively high oxygen and $\Delta \mathrm{N}_{2} \mathrm{O}$ values which corresponded to the secondary $\mathrm{N}_{2} \mathrm{O}$ maximum in the lower oxycline. Shallower subthermocline waters are covered by the Equatorial Subsurface Water (ESSW; $S \sim 34.8-35.2, T_{\text {pot }} \sim 9-14{ }^{\circ} \mathrm{C}$; Wyrtki, 1967). This water mass carried very low oxygen concentrations, while $\Delta \mathrm{N}_{2} \mathrm{O}$ values showed either a maximum or $\mathrm{N}_{2} \mathrm{O}$ depletion in this 

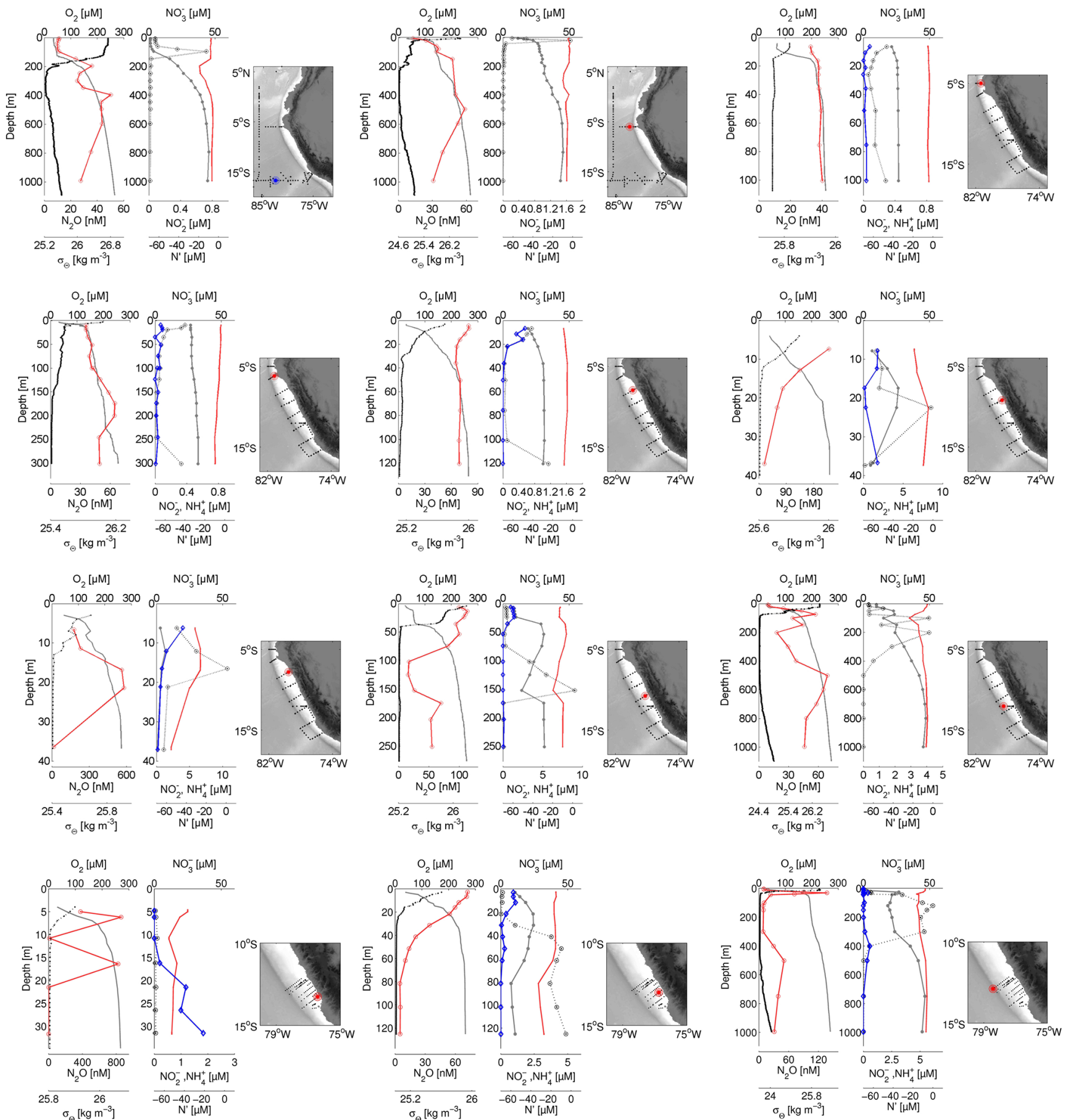

Figure 4. Selected depth profiles of oxygen (black dots, dotted line), potential density ( $\sigma_{\theta}$, grey line) and $\mathrm{N}_{2} \mathrm{O}$ (red line, open circles; left panel) and nitrate (grey line), nitrite (black circles, dotted line), ammonium (blue diamonds, straight line) and $\mathrm{N}^{\prime}$ (red line, small dots; right panel) from selected open-ocean and shelf stations during M90-93. Depth profiles of oxygen and $\sigma_{\theta}$ were taken from the CTD sensors, whereas the other parameters were taken from discrete samples. The locations of the respective stations are shown in the map. Red signals denote stations classified as "coastal" stations whereas blue signals denote "offshore" stations. Please note the changes in the scales for $\mathrm{N}_{2} \mathrm{O}$, $\sigma_{\theta}$, nitrite and ammonium. 

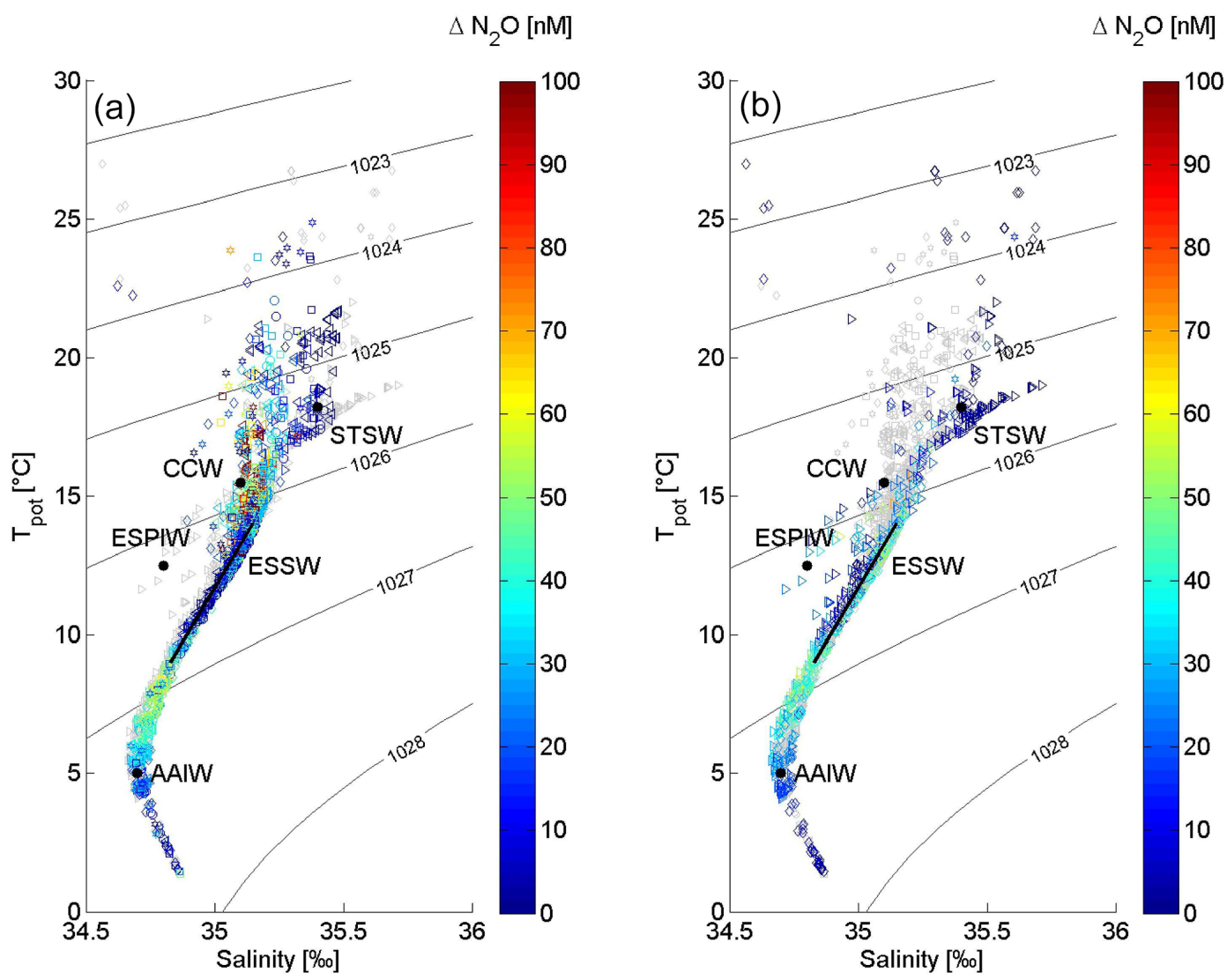

Figure 5. Temperature-salinity diagrams with $\Delta \mathrm{N}_{2} \mathrm{O}$ colour coded for (a) the offshore stations and (b) the onshore stations. Grey symbols denote the $T-S$ properties of (a) the onshore and (b) the offshore data. The approximate location of the different water masses annotated in the figure is given by black dots or lines. Different symbols denote different cruises: $\square$ M77-3; $\diamond$ M77-4; $\bigcirc$ M92; left pointing triangle: M90; right pointing triangle: M91; open hexagonal star:M93.

water mass, which reflects the strong sensitivity of net $\mathrm{N}_{2} \mathrm{O}$ consumption to variations in the oxygen concentration.

Waters with low salinities $(\sim 34.7)$, relatively high oxygen concentrations and potential temperatures between 10 and $15^{\circ} \mathrm{C}$ can be traced back to Eastern South Pacific Intermediate Water (ESPIW; Schneider et al., 2003). $\Delta \mathrm{N}_{2} \mathrm{O}$ values within this water mass were between 20 and $30 \mathrm{nM}$. Pietri et al. (2014) identified narrow patches of ESPIW below the thermocline about $\sim 100 \mathrm{~km}$ offshore. We hardly found this water mass in the coastal data, but it is likely mixed with the ESSW and surface waters on the shelf, where it contributes to the formation of Cold Coastal Water (CCW; Pietri et al., 2014). CCW with $S \sim 35.1$ and $T_{\text {pot }} \sim 15.5^{\circ} \mathrm{C}$ was prevalent over the shelf and could only be identified in the coastal data as it is directly related to the coastal upwelling. Offshore surface data were associated with Subtropical Surface Water (STSW) with salinities above 35.0 and temperatures higher than $17^{\circ} \mathrm{C}$ (Pietri et al., 2013), while surface waters at the coast showed properties that resulted from the warming of the CCW and the mixing with STSW.

Very variable $\Delta \mathrm{N}_{2} \mathrm{O}$ values were associated with the CCW and its related surface waters, and nearly all data points that showed extreme $\mathrm{N}_{2} \mathrm{O}$ accumulation fell within these waters. This indicates that the extremely high $\mathrm{N}_{2} \mathrm{O}$ concentrations were locally produced in the upwelling area, as none of the source water masses for the upwelling carried similarly high $\Delta \mathrm{N}_{2} \mathrm{O}$ values.

\section{$3.3 \Delta \mathrm{N}_{2} \mathrm{O} / \mathrm{AOU}$ relationship}

A two-linear $\Delta \mathrm{N}_{2} \mathrm{O} / \mathrm{AOU}$ relationship has been identified in the upper oxycline for waters with oxygen concentrations higher than $50 \mu \mathrm{M}$ and between 50 and $5 \mu \mathrm{M}$ during the M77-4 cruise that took place in the offshore waters of the OMZ (Ryabenko et al., 2012). We found a very similar relationship for all offshore data with oxygen concentrations above $50 \mu \mathrm{M}$ with no systematic difference between the data from the M77-4 (January/February 2009) cruise and the M90 (November 2012) cruise (Figs. 2, 6a). This indicates a comparable setting of the open-ocean $\mathrm{OMZ}$ waters during both cruises. We furthermore found no difference in the $\Delta \mathrm{N}_{2} \mathrm{O} / \mathrm{AOU}$ relationship between stations with a broad $\mathrm{N}_{2} \mathrm{O}$ maximum and a double-peak structure. These results are similar to previously reported $\Delta \mathrm{N}_{2} \mathrm{O} / \mathrm{AOU}$ relationships 

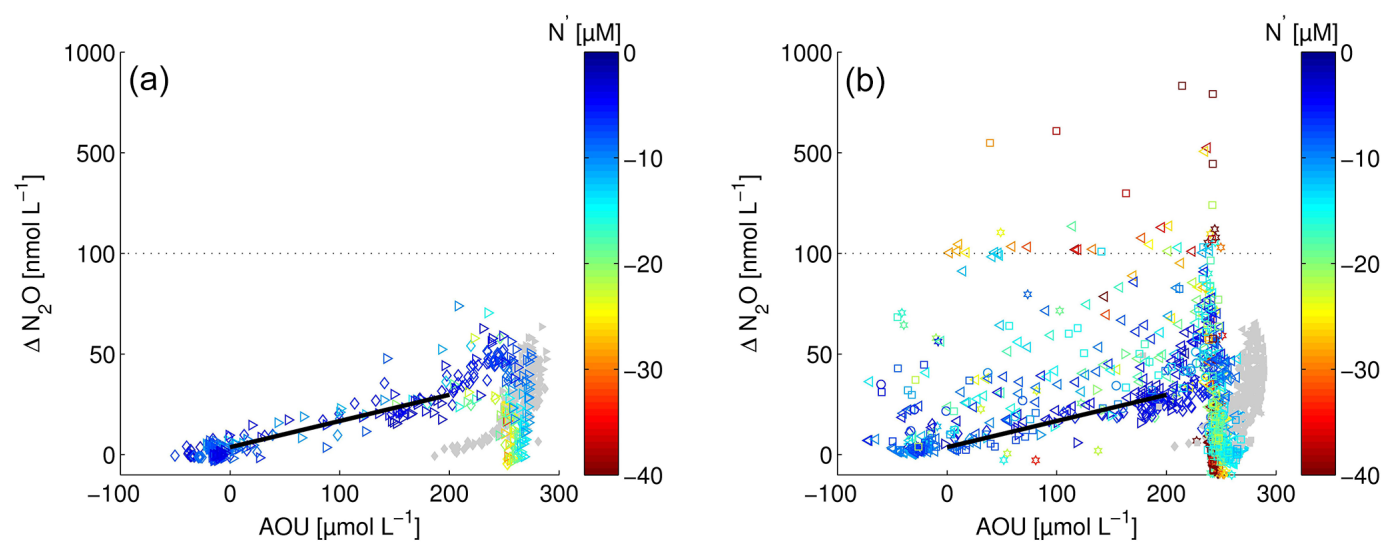

Figure 6. $\Delta \mathrm{N}_{2} \mathrm{O} /$ AOU relationship from (a) offshore stations and (b) coastal stations. Samples from the upper OMZ and oxycline (sample depth $<350 \mathrm{~m}$ ) are colour coded with $\mathrm{N}^{\prime}$, whereas samples from below $350 \mathrm{~m}$ are shown in grey. Different symbols for different cruises are denoted the same as in Fig. 5. The black line denotes the $\Delta \mathrm{N}_{2} \mathrm{O} /$ AOU relationship from the offshore data for samples with $\mathrm{O}_{2}>50 \mu \mathrm{M}$ and depth $<350 \mathrm{~m}\left(y=0.13 x+3.73 ; r^{2}=0.83\right)$. Please note the change in the scaling for $\Delta \mathrm{N}_{2} \mathrm{O}$ values of $0-100$ and $100-1000 \mathrm{nM}$ (dotted line).

from other oceanic OMZs (Upstill-Goddard et al., 1999; Cohen and Gordon, 1978; De Wilde and Helder, 1997).

In contrast to the open-ocean waters, a correlation between $\Delta \mathrm{N}_{2} \mathrm{O}$ and AOU was not observed for the coastal data (Fig. 6b). Numerous values with much higher $\Delta \mathrm{N}_{2} \mathrm{O} / \mathrm{AOU}$ ratios than in the offshore waters were observed. These data were highly scattered over the full range of oxygen concentrations. The $\Delta \mathrm{N}_{2} \mathrm{O}$ values that showed the strongest deviation from the offshore $\Delta \mathrm{N}_{2} \mathrm{O} /$ AOU ratio were associated with highly negative $\mathrm{N}^{\prime}$ values as a signal for a large nitrogen deficit (Fig. 6b). This indicates that these waters with extreme $\mathrm{N}_{2} \mathrm{O}$ accumulation had been subject to extensive $\mathrm{N}$ loss.

\section{Discussion}

To understand the differences between the offshore and the coastal $\mathrm{N}_{2} \mathrm{O}$ distribution in the Peruvian upwelling, the factors that influence $\mathrm{N}_{2} \mathrm{O}$ production or consumption during nitrification and denitrification need to be investigated.

In the oxycline waters of OMZs, peak $\mathrm{N}_{2} \mathrm{O}$ production from nitrification as well as denitrification has been determined under suboxic conditions, whereas $\mathrm{N}_{2} \mathrm{O}$ depletion was dominant in the OMZ core (Ji et al., 2015). Rate measurements however provided evidence that $\mathrm{N}_{2} \mathrm{O}$ production and consumption co-occur and that the interplay between $\mathrm{N}_{2} \mathrm{O}$ production and consumption processes regulates net $\mathrm{N}_{2} \mathrm{O}$ accumulation or depletion in the water column (Babbin et al., 2015). In open-ocean OMZs, however, $\mathrm{N}_{2} \mathrm{O}$ profiles reveal a remarkably stable shape which indicates that in these areas $\mathrm{N}_{2} \mathrm{O}$ production and consumption processes are well balanced (Babbin et al., 2015). Except for differences between the offshore $\mathrm{N}_{2} \mathrm{O}$ profiles with a broad $\mathrm{N}_{2} \mathrm{O}$ maximum north of $5^{\circ} \mathrm{S}$ and a double-peak structure south of $5^{\circ} \mathrm{S}$, the off- shore $\mathrm{N}_{2} \mathrm{O}$ profiles observed in our study indeed showed a relatively invariant $\mathrm{N}_{2} \mathrm{O}$ distribution. The differences in the shape of the $\mathrm{N}_{2} \mathrm{O}$ profiles can be explained by changing oxygen concentrations in the $\mathrm{OMZ}$ core and a threshold oxygen concentration of $5 \mu \mathrm{M}$ for net $\mathrm{N}_{2} \mathrm{O}$ consumption.

In areas where highly oxygen-deficient waters extended over the continental shelf, extreme accumulation of $\mathrm{N}_{2} \mathrm{O}$ has been found before in the Arabian Sea (Naqvi et al., 2010., 2006) and off Chile (Farías et al., 2015) and has been explained by rapid changes in the environmental conditions: Naqvi et al. (2000) explained the extreme $\mathrm{N}_{2} \mathrm{O}$ accumulation over the Indian shelf with the response of denitrifying enzymes to transient oxygen depletion. $\mathrm{N}_{2} \mathrm{O}$ thus accumulated when waters reached suboxic conditions. $\mathrm{N}_{2} \mathrm{O}$ accumulation coincided with the accumulation of nitrite and consumption of $\mathrm{N}_{2} \mathrm{O}$ started when these waters became sulfidic (Naqvi et al., 2010). Farías et al. (2015) measured $\mathrm{N}_{2} \mathrm{O}$ accumulation during the transition from oxic to anoxic conditions, too, but at variable oxygen concentrations whereas $\mathrm{N}_{2} \mathrm{O}$ depletion became dominant under suboxic conditions. In contrast to the results from the Indian Ocean, they identified enhanced remineralization due to short-term variability in coastal upwelling as the main driver for $\mathrm{N}_{2} \mathrm{O}$ accumulation.

The large variability we observed in the $\mathrm{N}_{2} \mathrm{O}$ distribution at the Peruvian coast could also be explained by an imbalance between $\mathrm{N}_{2} \mathrm{O}$ production and consumption processes that may lead to its accumulation. This could have been induced by rapid changes of the oxygen concentrations in the coastal upwelling zone: enhanced mixing of oxygenrich and oxygen-deficient waters and exchange of upwelled waters with the atmosphere supply oxygen to the water column (Schafstall et al., 2010; Thomsen et al., 2016; Pietri et al., 2014) while strong remineralization leads to rapid oxygen consumption (Kalvelage et al., 2015). Kalvelage et 
al. (2011) furthermore showed that these high remineralization rates also induce strong $\mathrm{N}$ cycling in the subsurface layer. Turnover rates for different $\mathrm{N}$ species are therefore much faster on the shelf than in the open-ocean $\mathrm{OMZ}(\mathrm{Hu}$ et al., 2015), which is also reflected in the distribution of different functional gene abundances (Löscher et al., 2014). Hence, it is likely that $\mathrm{N}_{2} \mathrm{O}$ production and consumption rates are much higher at the coast than in the offshore waters, and that short periods of increased $\mathrm{N}_{2} \mathrm{O}$ production could lead to very high $\mathrm{N}_{2} \mathrm{O}$ accumulation.

Changes in the oxygen concentrations could influence $\mathrm{N}_{2} \mathrm{O}$ production from nitrification as well as from denitrification: enhanced production of $\mathrm{N}_{2} \mathrm{O}$ after transition from anoxic to oxic conditions is a known process occurring in soils (e.g. Morley et al., 2008 ) and may be explained by a different sensitivity of denitrifying enzymes to trace concentrations of oxygen (Tiedje, 1988). In a recent incubation study, Dalsgaard et al. (2014) found no indication of increased $\mathrm{N}_{2} \mathrm{O}$ production by denitrification due to changes in the oxygen concentration at nanomolar levels, however. Instead, autotrophic denitrification and $\mathrm{N}_{2} \mathrm{O}$ production have been shown to be stimulated by the addition of hydrogen sulfide $\left(\mathrm{H}_{2} \mathrm{~S}\right.$; Galan et al., 2014; Dalsgaard et al., 2014). We did not find direct evidence for a coupling between $\mathrm{N}_{2} \mathrm{O}$ production and the presence of $\mathrm{H}_{2} \mathrm{~S}$ in our measurements, as high $\mathrm{N}_{2} \mathrm{O}$ accumulation was often found in proximity to $\mathrm{H}_{2} \mathrm{~S}$ plumes but was also detected when $\mathrm{H}_{2} \mathrm{~S}$ was absent in the water column. We cannot exclude that the high $\mathrm{N}_{2} \mathrm{O}$ production we frequently observed at the shelf was stimulated by a coupling of denitrification with sulfur cycling, though: Canfield et al. (2010) found evidence for active sulfur cycling in the ETSP without $\mathrm{H}_{2} \mathrm{~S}$ accumulation, and a coupling between $\mathrm{H}_{2} \mathrm{~S}$ oxidation and denitrification has been shown before (Galan et al., 2014; Jensen et al., 2009). Indeed, active denitrification was found in proximity to $\mathrm{H}_{2} \mathrm{~S}$ plumes in the water column during M77-3 (Kalvelage et al., 2013; Schunck et al., 2013).

In the ocean, increased $\mathrm{N}_{2} \mathrm{O}$ production was also associated with the onset of nitrification after re-ventilation of the water column in a seasonal study in the Baltic Sea, but with relatively low resulting $\mathrm{N}_{2} \mathrm{O}$ concentrations (Naqvi et al., 2010). Yu et al. (2010) found strongly increased $\mathrm{N}_{2} \mathrm{O}$ production by nitrifying bacteria that was stimulated by the availability of ammonium during recovery from anoxic conditions in a chemostat culture experiment. Their results point towards an increased $\mathrm{N}_{2} \mathrm{O}$ production via the ammonium-oxidation pathway, while $\mathrm{N}_{2} \mathrm{O}$ production by nitrifier-denitrification seemed not to be stimulated by the shift from anoxic to oxic conditions. We frequently measured high ammonium concentrations along the Peruvian shelf, indeed (Fig. 4), which could have stimulated $\mathrm{N}_{2} \mathrm{O}$ production from ammonium oxidation. A direct correlation between $\mathrm{N}_{2} \mathrm{O}$ and ammonium could not be identified, however.

From our concentration measurements alone we thus cannot distinguish whether the observed high production of $\mathrm{N}_{2} \mathrm{O}$ is a result of denitrification or nitrification processes. Studies of the isotopic and isotopomeric $\mathrm{N}_{2} \mathrm{O}$ composition and $\mathrm{N}_{2} \mathrm{O}$ production and consumption rate measurements could reveal more detailed insights into whether $\mathrm{N}_{2} \mathrm{O}$ is produced via the ammonium oxidation or the nitrite reduction pathway during its extreme accumulation.

In our study, we found strongly elevated $\mathrm{N}_{2} \mathrm{O}$ concentrations $(>100 \mathrm{nM})$ over the full range of oxygen concentrations, coinciding with strong $\mathrm{N}$ depletion (Fig. 5), but without nitrite accumulation (Fig. 4). The high oxygen concentrations found in the majority of our samples with extreme $\mathrm{N}_{2} \mathrm{O}$ accumulation and $\mathrm{N}$ depletion excludes in situ denitrification or anammox (see e.g. Babbin et al., 2014; Dalsgaard et al., 2014).

The extraordinarily high $\mathrm{N}_{2} \mathrm{O}$ concentrations as well as the low $\mathrm{N}^{\prime}$ values thus have to be old signals of processes taking place under anoxic to suboxic conditions. There is no known consumption process for $\mathrm{N}_{2} \mathrm{O}$ in oxygenated waters (Bange, 2008), and the strong signals of $\mathrm{N}$ loss that are produced under anoxic conditions are unlikely to be rapidly compensated by $\mathrm{N}$ fixation upon oxygenation. Both signals thus are likely to have remained preserved when oxygen concentrations increased due to mixing with waters of higher oxygen concentration or due to direct contact with the atmosphere as a result of upwelling.

Our observations of high $\mathrm{N}_{2} \mathrm{O}$ concentrations in oxygenated waters furthermore indicate that this accumulation could have taken place during re-oxygenation rather than during decreasing oxygen concentrations. An increase in oxygen concentrations would lead to the preservation of the high $\mathrm{N}_{2} \mathrm{O}$ signals in the water column whereas further decreasing oxygen concentrations would only lead to a temporal $\mathrm{N}_{2} \mathrm{O}$ accumulation and would eventually stimulate $\mathrm{N}_{2} \mathrm{O}$ consumption.

\section{Summary and conclusions}

We observed extreme $\mathrm{N}_{2} \mathrm{O}$ accumulations over the Peruvian shelf and in the adjacent waters with maximum concentrations similar to the observations by Naqvi et al. (2000) over the West Indian shelf and Farías et al. (2015) off Chile, whereas $\mathrm{N}_{2} \mathrm{O}$ concentrations in the open-ocean OMZ off Peru were comparably moderate. Similar to the findings by Naqvi et al. (2000), we found that $\mathrm{N}_{2} \mathrm{O}$ accumulation could be caused by enhanced $\mathrm{N}_{2} \mathrm{O}$ production by nitrification or denitrification under transient oxygen concentrations. We found strong evidence that these $\mathrm{N}_{2} \mathrm{O}$ accumulations are preserved when oxygen concentrations increased as a result of mixing and exchange with the overlying atmosphere in the upwelling zone. Waters with high $\mathrm{N}_{2} \mathrm{O}$ concentrations can thus be directly and frequently transported to the surface ocean. This makes this region one of the most important oceanic regions for $\mathrm{N}_{2} \mathrm{O}$ emissions to the atmosphere (Arévalo-Martínez et al., 2015). This direct link between un- 
usually high $\mathrm{N}_{2} \mathrm{O}$ production and emissions over the Peruvian shelf makes it necessary to understand the biogeochemical processes involved in $\mathrm{N}_{2} \mathrm{O}$ production and consumption to produce reliable predictions of oceanic emissions from this area. Current approaches to model the $\mathrm{N}_{2} \mathrm{O}$ distribution rely on parametrizations based on the linear $\Delta \mathrm{N}_{2} \mathrm{O} /$ AOU relationship (Suntharalingam and Sarmiento, 2000; Nevison et al., 2003; Freing et al., 2012). These approaches could in fact reproduce the oxygen distribution in the open-ocean $\mathrm{OMZ}$ off Peru reasonably well, but they fail to account for the extreme $\mathrm{N}_{2} \mathrm{O}$ accumulation and its high spatial and temporal variability over the shelf area. They thus significantly underestimate the emissions from the Peruvian upwelling and potentially other upwelling areas with similar conditions, too.

Author contributions. A. Kock, D. Arévalo-Martínez, H. Bange and $\mathrm{C}$. Löscher designed the sampling strategy and conducted the $\mathrm{N}_{2} \mathrm{O}$ sampling and measurements. A. Kock and C. Löscher analysed the $\mathrm{N}_{2} \mathrm{O}$ measurement data and calculated in situ $\mathrm{N}_{2} \mathrm{O}$ concentrations. A. Kock conducted the further data analysis and wrote the paper with contributions from all co-authors.

Acknowledgements. We would like to thank the captains and crew of the R/V Meteor for their professional support and the chief scientists of M77-3\&4 and M90-M93, Martin Frank, Lothar Stramma, Stefan Sommer and Gaute Lavik for the opportunity to collect samples during their cruises. We would also like to thank Annie Bourbonnais and Johanna Maltby for the collection of $\mathrm{N}_{2} \mathrm{O}$ samples during M92, and Gesa Eirund, Joel Craig, Georgina Flores, Jennifer Zur, Moritz Baumann, Tina Baustian and Dörte Nitschkowski for their help in analysing the samples.

We would like to thank Frank Malien, Mirja Dunker, Violeta Leon, Peter Fritsche, Tina Baustian, Kerstin Nachtigall, Martina Lohmann, Gabriele Klockgether and Tim Kalvelage for the sampling and analysis of oxygen and nutrient samples during M77-3 and M77-4 and M90-M93. The work presented here was made possible by the DFG-supported projects SFB754 Phase I and II (http://www.sfb754.de) and the BMBF joint projects SOPRAN II and III (FKZ 03F0611A and FKZ 03F662A).

Edited by: S. W. A. Naqvi

\section{References}

Altabet, M. A., Ryabenko, E., Stramma, L., Wallace, D. W. R., Frank, M., Grasse, P., and Lavik, G.: An eddy-stimulated hotspot for fixed nitrogen-loss from the Peru oxygen minimum zone, Biogeosciences, 9, 4897-4908, doi:10.5194/bg-9-48972012, 2012.

Arévalo-Martínez, D. L., Beyer, M., Krumbholz, M., Piller, I., Kock, A., Steinhoff, T., Körtzinger, A., and Bange, H. W.: A new method for continuous measurements of oceanic and atmospheric $\mathrm{N}_{2} \mathrm{O}, \mathrm{CO}$ and $\mathrm{CO}_{2}$ : performance of off-axis integrated cavity output spectroscopy (OA-ICOS) coupled to non- dispersive infrared detection (NDIR), Ocean Sci., 9, 1071-1087, doi:10.5194/os-9-1071-2013, 2013.

Arévalo-Martínez, D. L., Kock, A., Löscher, C. R., Schmitz, R. A., and Bange, H. W.: Massive nitrous oxide emissions from the tropical South Pacific Ocean, Nat. Geosci., 8, 530-533, doi:10.1038/ngeo2469, 2015.

Arp, D. J. and Stein, L. Y.: Metabolism of inorganic N compounds by ammonia-oxidizing bacteria, Critical Reviews in Biochemistry and Molecular Biology, 38, 471-495, doi:10.1080/10409230390267446, 2003.

Babbin, A. R., Keil, R. G., Devol, A. H., and Ward, B. B.: Organic Matter Stoichiometry, Flux, and Oxygen Control Nitrogen Loss in the Ocean, Science, 344, 406-408, doi:10.1126/science.1248364, 2014.

Babbin, A. R., Bianchi, D., Jayakumar, A., and Ward, B. B.: Rapid nitrous oxide cycling in the suboxic ocean, Science, 348, 11271129, doi:10.1126/science.aaa8380, 2015.

Bange, H. W.: Gaseous nitrogen compounds (NO,N2O,N2,NH3) in the ocean, in: Nitrogen in the Marine Environment, 2 ed., edited by: Capone, D. G., Bronk, D. A., Mulholland, M. R., and Carpenter, E. J., Academic Press/Elsevier 51-94, 2008.

Bange, H. W., Andreae, M. O., Lal, S., Law, C. S., Naqvi, S. W. A., Patra, P. K., Rixen, T., and Upstill-Goddard, R. C.: Nitrous oxide emissions from the Arabian Sea: A synthesis, Atmos. Chem. Phys., 1, 61-71, doi:10.5194/acp-1-61-2001, 2001.

Canfield, D. E., Stewart, F. J., Thamdrup, B., De Brabandere, L., Dalsgaard, T., Delong, E. F., Revsbech, N. P., and U1loa, O.: A Cryptic Sulfur Cycle in Oxygen-Minimum-Zone Waters off the Chilean Coast, Science, 330, 1375-1378, doi:10.1126/science.1196889, 2010.

Chaigneau, A., Dominguez, N., Eldin, G., Vasquez, L., Flores, R., Grados, C., and Echevin, V.: Near-coastal circulation in the Northern Humboldt Current System from shipboard ADCP data, J. Geophys. Res.-Oceans, 118, 5251-5266, doi:10.1002/jgrc.20328, 2013.

Chang, B. X., Rich, J. R., Jayakumar, A., Naik, H., Pratihary, A. K., Keil, R. G., Ward, B. B., and Devol, A. H.: The effect of organic carbon on fixed nitrogen loss in the eastern tropical South Pacific and Arabian Sea oxygen deficient zones, Limnol. Oceanogr., 59, 1267-1274, doi:10.4319/lo.2014.59.4.1267, 2014.

Charpentier, J., Farias, L., and Pizarro, O.: Nitrous oxide fluxes in the central and eastern South Pacific, Global Biogeochem. Cy., 24, Gb3011, doi:10.1029/2008gb003388, 2010.

Chavez, F. P. and Messié, M.: A comparison of Eastern Boundary Upwelling Ecosystems, Prog. Oceanogr., 83, 80-96, 2009.

Chelton, D. B., DeSzoeke, R. A., Schlax, M. G., El Naggar, K., and Siwertz, N.: Geographical variability of the first baroclinic Rossby radius of deformation, Journal of Physical Oceanography, 28, 433-460, doi:10.1175/15200485(1998)028<0433:gvotfb>, 2.0.co;2, 1998.

Ciais, P., Sabine, C. L., Bala, G., Bopp, L., Brovkin, V., Canadell, J., Chhabra, A., DeFries, R., Galloway, J. N., Heimann, M., Jones, C., Le Quéré, C., Myneni, R., Piao, S., and Thornton, P.: Carbon and other Biogeochemical Cycles, in: Climate Change 2013: The Physical Science Basis. Contribution of Working Group I to the Fifth Assessment Report of the Intergovernmental Panel on Climate Change, edited by: Stocker, T. F., Qin, D., Plattner, G.-K., Tignor, M., Allen, S. K., Boschung, J., Nauels, A., Xia, Y., Bex, 
V., and Midgley, P. M., Cambridge University Press, Cambridge, UK, and New York, NY, USA, 465-570, 2013.

Codispoti, L. A. and Christensen, J. P.: Nitrification, denitrification and nitrous oxide cycling in the eastern tropical South Pacific Ocean, Mar. Chem., 16, 277-300, 1985.

Codispoti, L. A., Friederich, G. E., Packard, T. T., Glover, H. E., Kelly, P. J., Spinrad, R. W., Barber, R. T., Elkins, J. W., Ward, B. B., Lipschultz, F., and Lostaunau, N.: High nitrite levels off northern Peru: A signal of instability in the marine denitrification rate, Science, 233, 1200-1202, 1986.

Cohen, Y. and Gordon, L. I.: Nitrous oxide in oxygen minimum of eastern tropical North Pacific - evidence for its consumption during denitrification and possible mechanisms for its production, Deep-Sea Res., 25, 509-524, doi:10.1016/0146-6291(78)906409, 1978.

Cornejo, M. and Farías, L.: Following the $\mathrm{N}_{2} \mathrm{O}$ consumption in the oxygen minimum zone of the eastern South Pacific, Biogeosciences, 9, 3205-3212, doi:10.5194/bg-9-3205-2012, 2012.

Dalsgaard, T., Stewart, F. J., Thamdrup, B., De Brabandere, L., Revsbech, N. P., Ulloa, O., Canfield, D. E., and DeLong, E. F.: Oxygen at Nanomolar Levels Reversibly Suppresses Process Rates and Gene Expression in Anammox and Denitrification in the Oxygen Minimum Zone off Northern Chile, Mbio, 5, e01966, doi:10.1128/mBio.01966-14, 2014.

De Wilde, H. P. J. and Helder, W.: Nitrous oxide in the Somali Basin: the role of upwelling, Deep-Sea Res. Pt. II, 44, 13191340, doi:10.1016/S0967-0645(97)00011-8, 1997.

Dewitte, B., Vazquez-Cuervo, J., Goubanova, K., Illig, S., Takahashi, K., Cambon, G., Purca, S., Correa, D., Gutierrez, D., Sifeddine, A., and Ortlieb, L.: Change in El Nino flavours over 1958-2008: Implications for the long-term trend of the upwelling off Peru, Deep-Sea Res. Pt. II, 77-80, 143-156, doi:10.1016/j.dsr2.2012.04.011, 2012.

Echevin, V., Aumont, O., Ledesma, J., and Flores, G.: The seasonal cycle of surface chlorophyll in the Peruvian upwelling system: A modelling study, Prog. Oceanogr., 79, 167-176, doi:10.1016/j.pocean.2008.10.026, 2008.

Farias, L., Paulmier, A., and Gallegos, M.: Nitrous oxide and Nnutrient cycling in the oxygen minimum zone off northern Chile, Deep-Sea Res. Pt. I, 54, 164-180, doi:10.1016/j.dsr.2006.11.003, 2007.

Farias, L., Castro-Gonzalez, M., Cornejo, M., Charpentier, J., Faundez, J., Boontanon, N., and Yoshida, N.: Denitrification and nitrous oxide cycling within the upper oxycline of the eastern tropical South Pacific oxygen minimum zone, Limnol. Oceanogr., 54, 132-144, 2009.

Farías, L., Besoain, V., and García-Loyola, S.: Presence of nitrous oxide hotspots in the coastal upwelling area off central Chile: an analysis of temporal variability based on ten years of a biogeochemical time series, Environ. Res. Lett., 10, 044017, doi:10.1088/1748-9326/10/4/044017, 2015.

Firestone, M. K., Firestone, R. B., and Tiedje, J. M.: Nitrous-oxide from soil denitrification - factors controlling its biological production, Science, 208, 749-751, doi:10.1126/science.208.4445.749, 1980.

Forster, G., Upstill-Goddard, R. C., Gist, N., Robinson, C., Uher, G., and Woodward, E. M. S.: Nitrous oxide and methane in the Atlantic Ocean between 50 degrees $\mathrm{N}$ and 52 degrees S: Latitu- dinal distribution and sea-to-air flux, Deep-Sea Res. Pt. II, 56, 964-976, doi:10.1016/j.dsr2.2008.12.002, 2009.

Freing, A., Wallace, D. W. R., Tanhua, T., Walter, S., and Bange, H. W.: North Atlantic production of nitrous oxide in the context of changing atmospheric levels, Global Biogeochem. Cy., 23, GB4015, doi:10.1029/2009gb003472, 2009.

Freing, A., Wallace, D. W. R., and Bange, H. W.: Global oceanic production of nitrous oxide, Philos. T. Roy. Soc. B, 367, 12451255, doi:10.1098/rstb.2011.0360, 2012.

Fuenzalida, R., Schneider, W., Garcés-Vargas, J., Bravo, L., and Lange, C.: Vertical and horizontal extension of the oxygen minimum zone in the eastern South Pacific Ocean, Deep-Sea Res. Pt. II, 56, 992-1003, 2009.

Galan, A., Faundez, J., Thamdrup, B., Francisco Santibanez, J., and Farias, L.: Temporal dynamics of nitrogen loss in the coastal upwelling ecosystem off central Chile: Evidence of autotrophic denitrification through sulfide oxidation, Limnol. Oceanogr., 59, 1865-1878, doi:10.4319/lo.2014.59.6.1865, 2014.

Goreau, T. J., Kaplan, W. A., Wofsy, S. C., McElroy, M. B., Valois, F. W., and Watson, S. W.: Production of $\mathrm{NO}_{2}^{-}$and $\mathrm{N}_{2} \mathrm{O}$ by nitrifying bacteria at reduced concentrations of oxygen, Appl. Environ. Microbiol., 40, 526-532, 1980.

Graco, M., Purca, S., Dewitte, B., Morón, O., Ledesma, J., Flores, G., Castro, C., and Gutiérrez, D.: The OMZ and nutrients features as a signature of interannual and low frequency variability off the peruvian upwelling system, Biogeosciences Discuss., 2016, 1-36, doi:10.5194/bg-2015-567, 2016.

Grasshoff, K., Kremling, K., and Ehrhardt, M.: Methods of seawater analysis, 3rd ed., Wiley-VCH, New York, 600 pp., 1999.

Gutierrez, D., Enriquez, E., Purca, S., Quipuzcoa, L., Marquina, R., Flores, G., and Graco, M.: Oxygenation episodes on the continental shelf of central Peru: Remote forcing and benthic ecosystem response, Prog. Oceanogr., 79, 177-189, doi:10.1016/j.pocean.2008.10.025, 2008.

Hamersley, M. R., Lavik, G., Woebken, D., Rattray, J. E., Lam, P., Hopmans, E. C., Sinninghe Damste, J. S., Krueger, S., Graco, M., Gutierrez, D., and Kuypers, M. M. M.: Anaerobic ammonium oxidation in the Peruvian oxygen minimum zone, Limnol. Oceanogr., 52, 923-933, 2007.

Hansen, H. P., and Koroleff, F.: Determination of nutrients, in: Methods of seawater analysis, edited by: Grasshoff, K., Kremling, K., and Ehrhardt, M., Wiley-VCH, Weinheim, 159-228, 1999.

Hu, H., Bourbonnais, A., Larkum, J., Bange, H. W., and Altabet, M. A.: Nitrogen cycling in shallow low oxygen coastal waters off Peru from nitrite and nitrate nitrogen and oxygen isotopes, Biogeosciences Discuss., 12, 7257-7299, doi:10.5194/bgd-12-72572015, 2015.

IPCC: Climate Change 2013: The Physical Science Basis. Contribution of Working Group I to the Fifth Assessment Report of the Intergovernmental Panel on Climate Change, Cambridge, UK and New York, NY, 1535 pp., 2013.

Jensen, M. M., Petersen, J., Dalsgaard, T., and Thamdrup, B.: Pathways, rates, and regulation of $\mathrm{N}-2$ production in the chemocline of an anoxic basin, Mariager Fjord, Denmark, Mar. Chem., 113, 102-113, doi:10.1016/j.marchem.2009.01.002, 2009.

Ji, Q., Babbin, A. R., Jayakumar, A., Oleynik, S., and Ward, B. B.: Nitrous oxide production by nitrification and denitrification in the Eastern Tropical South Pacific oxygen minimum zone, 
Geophys. Res. Lett., 42, GL066853, doi:10.1002/2015g1066853, 2015.

Kalvelage, T., Jensen, M. M., Contreras, S., Revsbech, N. P., Lam, P., Guenter, M., LaRoche, J., Lavik, G., and Kuypers, M. M. M.: Oxygen Sensitivity of Anammox and Coupled N-Cycle Processes in Oxygen Minimum Zones, Plos One, 6, e29299, doi:10.1371/journal.pone.0029299, 2011.

Kalvelage, T., Lavik, G., Lam, P., Contreras, S., Arteaga, L., Loescher, C. R., Oschlies, A., Paulmier, A., Stramma, L., and Kuypers, M. M. M.: Nitrogen cycling driven by organic matter export in the South Pacific oxygen minimum zone, Nat. Geosci., 6, 228-234, doi:10.1038/ngeo1739, 2013.

Kalvelage, T., Lavik, G., Jensen, M. M., Revsbech, N. P., Loescher, C., Schunck, H., Desai, D. K., Hauss, H., Kiko, R., Holtappels, M., LaRoche, J., Schmitz, R. A., Graco, M. I., and Kuypers, M. M. M.: Aerobic Microbial Respiration In Oceanic Oxygen Minimum Zones, Plos One, 10, e0133526, doi:10.1371/journal.pone.0133526, 2015.

Karstensen, J., Stramma, L., and Visbeck, M.: Oxygen minimum zones in the eastern tropical Atlantic and Pacific oceans, Prog. Oceanogr., 77, 331-350, doi:10.1016/j.pocean.2007.05.009, 2008.

Kock, A. and Bange, H. W.: Counting the ocean's greenhouse gas emissions, Eos, 96, 10-13, doi:10.1029/2015EO023665, 2015.

Law, C. S. and Owens, N. J. P.: Significant flux of atmospheric nitrous oxide from the Northwest Indian Ocean, Nature, 346, 826828, doi:10.1038/346826a0, 1990.

Löscher, C. R., Kock, A., Könneke, M., LaRoche, J., Bange, H. W., and S chmitz, R. A.: Production of oceanic nitrous oxide by ammonia-oxidizing archaea, Biogeosciences, 9, 2419-2429, doi:10.5194/bg-9-2419-2012, 2012.

Löscher, C. R., Grosskopf, T., Desai, F. D., Gill, D., Schunck, H., Croot, P. L., Schlosser, C., Neulinger, S. C., Pinnow, N., Lavik, G., Kuypers, M. M. M., LaRoche, J., and Schmitz, R. A.: Facets of diazotrophy in the oxygen minimum zone waters off Peru, Isme J., 8, 2180-2192, doi:10.1038/ismej.2014.71, 2014.

McDougall, T. J. and Barker, P. M.: Getting started with TEOS10 and the Gibbs Seawater (GSW) Oceanographic Toolbox, SCOR/IAPSO WG127, 28 pp., 2011.

Messie, M., Ledesma, J., Kolber, D. D., Michisaki, R. P., Foley, D. G., and Chavez, F. P.: Potential new production estimates in four eastern boundary upwelling ecosystems, Prog. Oceanogr., 83, 151-158, doi:10.1016/j.pocean.2009.07.018, 2009.

Montes, I., Colas, F., Capet, X., and Schneider, W.: On the pathways of the equatorial subsurface currents in the eastern equatorial Pacific and their contributions to the PeruChile Undercurrent, J. Geophys. Res.-Oceans, 115, C09003, doi:10.1029/2009jc005710, 2010.

Morley, N., Baggs, E. M., Dorsch, P., and Bakken, L.: Production of $\mathrm{NO}, \mathrm{N}(2) \mathrm{O}$ and $\mathrm{N}(2)$ by extracted soil bacteria, regulation by $\mathrm{NO}(2)(-)$ and $\mathrm{O}(2)$ concentrations, FEMS Microbiol. Ecol., 65, 102-112, doi:10.1111/j.1574-6941.2008.00495.x, 2008.

Naqvi, S. W. A., Jayakumar, D. A., Narveka, P. V., Naik, H., Sarma, V. V. S. S., D'Souza, W., Joseph, S., and George, M. D.: Increased marine production of $\mathrm{N}_{2} \mathrm{O}$ due to intensifying anoxia on the Indian continental shelf, Nature, 408, 346-349, 2000.

Naqvi, S. W. A., Naik, H., Pratihary, A., D’Souza, W., Narvekar, P. V., Jayakumar, D. A., Devol, A. H., Yoshinari, T., and Saino,
T.: Coastal versus open-ocean denitrification in the Arabian Sea, Biogeosciences, 3, 621-633, doi:10.5194/bg-3-621-2006, 2006.

Naqvi, S. W. A., Bange, H. W., Farías, L., Monteiro, P. M. S., Scranton, M. I., and Zhang, J.: Marine hypoxia/anoxia as a source of $\mathrm{CH}_{4}$ and $\mathrm{N}_{2} \mathrm{O}$, Biogeosciences, 7, 2159-2190, doi:10.5194/bg7-2159-2010, 2010.

Nevison, C., Butler, J. H., and Elkins, J. W.: Global distribution of $\mathrm{N} 2 \mathrm{O}$ and the Delta $\mathrm{N}_{2} \mathrm{O}-\mathrm{AOU}$ yield in the subsurface ocean, Global Biogeochem. Cy., 17, 1119, doi:10.1029/2003gb002068, 2003.

Nevison, C. D., Lueker, T. J., and Weiss, R. F.: Quantifying the nitrous oxide source from coastal upwelling, Global Biogeochem. Cy., 18, GB1018, doi:10.1029/2003GB002110, 2004.

Ni, B.-J., Peng, L., Law, Y., Guo, J., and Yuan, Z.: Modeling of Nitrous Oxide Production by Autotrophic Ammonia-Oxidizing Bacteria with Multiple Production Pathways, Environ. Sci. Technol., 48, 3916-3924, doi:10.1021/es405592h, 2014.

Ostrom, N. E., Russ, M. E., Popp, B., Rust, T. M., and Karl, D. M.: Mechanisms of nitrous oxide production in the subtropical North Pacific based on determinations of the isotopic abundances of nitrous oxide and di-oxygen, Chemosphere - Global Change Science, 2, 281-290, 2000.

Paulmier, A., Ruiz-Pino, D., Garcon, V., and Farias, L.: Maintaining of the Eastern South Pacific Oxygen Minimum Zone (OMZ) off Chile, Geophys. Res. Lett., 33, L20601, doi:10.1029/2006g1026801, 2006.

Pennington, J. T., Mahoney, K. L., Kuwahara, V. S., Kolber, D. D., Calienes, R., and Chavez, F. P.: Primary production in the eastern tropical Pacific: A review, Prog. Oceanogr., 69, 285-317, doi:10.1016/j.pocean.2006.03.012, 2006.

Pietri, A., Testor, P., Echevin, V., Chaigneau, A., Mortier, L., Eldin, G., and Grados, C.: Finescale Vertical Structure of the Upwelling System off Southern Peru as Observed from Glider Data, J. Phys. Oceanogr., 43, 631-646, doi:10.1175/jpo-d-12-035.1, 2013.

Pietri, A., Echevin, V., Testor, P., Chaigneau, A., Mortier, L., Grados, C., and Albert, A.: Impact of a coastal-trapped wave on the near-coastal circulation of the Peru upwelling system from glider data, J. Geophys. Res.-Oceans, 119, 2109-2120, doi:10.1002/2013jc009270, 2014.

Ryabenko, E., Kock, A., Bange, H. W., Altabet, M. A., and Wallace, D. W. R.: Contrasting biogeochemistry of nitrogen in the Atlantic and Pacific Oxygen Minimum Zones, Biogeosciences, 9, 203 215, doi:10.5194/bg-9-203-2012, 2012.

Santoro, A. E., Buchwald, C., McIlvin, M. R., and Casciotti, K. L.: Isotopic Signature of $\mathrm{N}(2) \mathrm{O}$ Produced by Marine Ammonia-Oxidizing Archaea, Science, 333, 1282-1285, doi:10.1126/science.1208239, 2011.

Schafstall, J., Dengler, M., Brandt, P., and Bange, H.: Tidalinduced mixing and diapycnal nutrient fluxes in the Mauritanian upwelling region, J. Geophys. Res.-Oceans, 115, C10014, doi:10.1029/2009jc005940, 2010.

Schneider, W., Fuenzalida, R., Rodriguez-Rubio, E., Garces-Vargas, J., and Bravo, L.: Characteristics and formation of eastern South Pacific intermediate water, Geophys. Res. Lett., 30, 1581, doi:10.1029/2003g1017086, 2003.

Schunck, H., Lavik, G., Desai, D. K., Grosskopf, T., Kalvelage, T., Loescher, C. R., Paulmier, A., Contreras, S., Siegel, H., Holtappels, M., Rosenstiel, P., Schilhabel, M. B., Graco, M., Schmitz, R. A., Kuypers, M. M. M., and LaRoche, J.: Gi- 
ant Hydrogen Sulfide Plume in the Oxygen Minimum Zone off Peru Supports Chemolithoautotrophy, Plos One, 8, e68661, doi:10.1371/journal.pone.0068661, 2013.

Stein, L. Y.: Surveying $\mathrm{N}_{2} \mathrm{O}$-producing pathways in bacteria, in: Methods in Enzymology: Research on Nitrification and Related Processes, Part A, edited by: Klotz, M. G., Methods in Enzymology, 486, 131-152, 2011.

Stieglmeier, M., Mooshammer, M., Kitzler, B., Wanek, W., Zechmeister-Boltenstern, S., Richter, A., and Schleper, C.: Aerobic nitrous oxide production through $\mathrm{N}$-nitrosating hybrid formation in ammonia-oxidizing archaea, Isme J., 8, 1135-1146, doi:10.1038/ismej.2013.220, 2014.

Stramma, L., Johnson, G. C., Firing, E., and Schmidtko, S.: Eastern Pacific oxygen minimum zones: Supply paths and multidecadal changes, J. Geophys. Res.-Oceans, 115, C09011, doi:10.1029/2009jc005976, 2010.

Suntharalingam, P. and Sarmiento, J. L.: Factors governing the oceanic nitrous oxide distribution: Simulations with an ocean general circulation model, Global Biogeochem. Cy., 14, 429454, doi:10.1029/1999gb900032, 2000.

Thamdrup, B., Dalsgaard, T., Jensen, M. M., Ulloa, O., Farias, L., and Escribano, R.: Anaerobic ammonium oxidation in the oxygen-deficient waters off northern Chile, Limnol. Oceanogr., 51, 2145-2156, 2006.

Thamdrup, B., Dalsgaard, T., and Revsbech, N. P.: Widespread functional anoxia in the oxygen minimum zone of the Eastern South Pacific, Deep-Sea Res. Pt. I, 65, 36-45, doi:10.1016/j.dsr.2012.03.001, 2012.

Thomsen, S., Kanzow, T., Krahmann, G., Greatbatch, R. J., Dengler, M., and Lavik, G.: The formation of a subsurface anticyclonic eddy in the Peru-Chile Undercurrent and its impact on the nearcoastal salinity, oxygen, and nutrient distributions, J. Geophys. Res.-Oceans, doi:10.1002/2015jc010878, 2016.

Tiedje, J. M.: Ecology of denitrification and dissimilatory nitrate reduction to ammonium, in: Biology of anearobic microorganisms, edited by: Zehnder, A. J. B., Wiley \& Sons, New York, 179-244, 1988.
Upstill-Goddard, R. C., Barnes, J., and Owens, N. J. P.: Nitrous oxide and methane during the 1994 SW monsoon in the Arabian Sea/northwestern Indian Ocean, J. Geophys. Res.-Oceans, 104, 30067-30084, doi:10.1029/1999jc900232, 1999.

Walker, C. B., de la Torre, J. R., Klotz, M. G., Urakawa, H., Pinel, N., Arp, D. J., Brochier-Armanet, C., Chain, P. S. G., Chan, P. P., Gollabgir, A., Hemp, J., Hugler, M., Karr, E. A., Konneke, M., Shin, M., Lawton, T. J., Lowe, T., MartensHabbena, W., Sayavedra-Soto, L. A., Lang, D., Sievert, S. M., Rosenzweig, A. C., Manning, G., and Stahl, D. A.: Nitrosopumilus maritimus genome reveals unique mechanisms for nitrification and autotrophy in globally distributed marine crenarchaea, P. Natl. Acad. Sci. USA, 107, 8818-8823, doi:10.1073/pnas.0913533107, 2010.

Walter, S., Bange, H. W., Breitenbach, U., and Wallace, D. W. R.: Nitrous oxide in the North Atlantic Ocean, Biogeosciences, 3, 607-619, doi:10.5194/bg-3-607-2006, 2006.

Weiss, R. F. and Price, B. A.: Nitrous oxide solubility in water and seawater, Mar. Chem., 8, 347-359, 1980.

WMO: Scientific Assessment of Ozone Depletion: 2010, Global Ozone Research and Monitoring Project, Geneva, Switzerland, 2011.

Wyrtki, K.: CIRCULATION AND WATER MASSES IN EASTERN EQUATORIAL PACIFIC OCEAN, Int. J. Oceanol. Limnol., 1, 117-147, 1967.

Yu, R., Kampschreur, M. J., Loosdrecht, M. C. M. v., and Chandran, K.: Mechanisms and Specific Directionality of Autotrophic Nitrous Oxide and Nitric Oxide Generation during Transient Anoxia, Environ. Sci. Technol., 44, 1313-1319, doi:10.1021/es902794a, 2010.

Zamora, L. M., Oschlies, A., Bange, H. W., Huebert, K. B., Craig, J. D., Kock, A., and Löscher, C. R.: Nitrous oxide dynamics in low oxygen regions of the Pacific: insights from the MEMENTO database, Biogeosciences, 9, 5007-5022, doi:10.5194/bg-9-5007-2012, 2012. 